\title{
ANALYSIS OF TECHNICAL EFFICIENCY AND COMPETITIVENESS OF MAIZE FARMING IN GORONTALO PROVINCE, INDONESIA
}

\author{
Mantau Zulkifli* \\ Gorontalo Assessment Institute of Agricultural Technology at Indonesia Agricultural \\ Research \& Development Agency, Indonesia
}

Hanani AR Nuhfil, Mustadjab M. Muslich, Syafrial

Agricultural Economics Department, Faculty of Agriculture, University of Brawijaya, Indonesia

*E-mail: mantau66@yahoo.com

\begin{abstract}
This research aims to analyze the technical efficiency and the competitiveness level of maize farming in Gorontalo Province, Indonesia. The results showed that there are 3 variables of technical efficiency that influence significantly to maize production, such a planted area, seed quantity and NPK fertilizer. Meanwhile, 6 variables of inefficiency effect (farmer ages, farm experience, education level, member of household, total land area, and total incomes) has no influence to the maize production, significantly. The efficiency of farms is on the level of 0.66 (not efficient) which indicates that maize farm could produce, on average, $34 \%$ by using of a given set of inputs. PAM results showed that the maize farming in Gorontalo is no longer competitive because Domestic Resources Cost Ratio (DRCR) and Private Cost Ratio (PCR) were 1.85 and 3.81, respectively. Overall, the output and input policies of government were not effective to increase the production and competitiveness of maize farming in Gorontalo Province. To solve this problem, the government must reorganize the tax policy of commodity, distribution cost subsidy and the most important is the government purchase price policy. The mutual cooperation in farming is better to be a legally by government to solve the inefficiency and high cost problems of farm labor.
\end{abstract}

\section{KEY WORDS}

Maize farming, technical efficiency, stochastic frontier analysis, policy analysis matrix, competitiveness.

Gorontalo maize since 2001 has become a mainstay export commodity. The largest export volume occurred in 2008 of 84448 tons. Unfortunately, it was decline in the following years. BPS-Statistics data (2010) shows that in the last two years (2009 - 2010) export volume of Gorontalo maize decreased from 42942.46 tons to 32,187 tons with the value of Freight on Board (FOB) US $\$ 7,641,544$ and decreased in 2011 by 8400 ton with FOB value of US \$2,225,040 (BPS-Statistics of Gorontalo Province, 2011). However, in 2014, exports of Gorontalo maize increased by 32460 tons with a value of US $\$ 8,516,868$. While in 2015 , BPS-Statistics noted that Gorontalo maize exports reached 85.25 percent of Gorontalo's total exports in the year which amounted to US \$31,381,776 (BPS-Statistics of Gorontalo Province, 2016). Meanwhile, the currently export of this commodity was happen in February 2018 with 3850000 tons export volume and export value of US $\$ 1,014,475$. This is the first export of Indonesia maize in 2018 (data of Gorontalo Customs, 2018).

The fluctuations of maize exports in Gorontalo that tend to decline every year is thought to be the impact of fluctuations problem in production of maize and decrease of harvested area. The 2016 Agricultural Census Data shows that the harvest area of Gorontalo's maize was decline from 156436 ha in 2008 to 129131 ha in 2015. In absolute terms, there was a decrease of 27.31 ha within 7 years. Similarly, production fluctuated during this period, where there was a sharp decline in the last 2 years (2014-2015), from 719 787 tons to 643512 tons (down 11 tons) (www.bps.go.id, accessible May 22, 2017). In additional, to be said to have competitiveness (especially comparative advantages), 
Gorontalo maize should be able to be produced by itself with existing domestic resource condition and have efficiency in production inputs. So that, the region can compete in competitive market with the competitor countries or other regions in Indonesia.

The production and competitiveness are two things that cannot be separated from each other. Because, generally, the increase of production and price of commodity will be followed by the increase of commodity competitiveness and vice versa. In principle, production is a process of transformation of some inputs into a form of output that has an economic value. Thus, Doll and Orazem (1984) argue that the main concepts in the production economy are about the costs of farming, both the input and output costs or the responses between the both, and the use of natural and human resources for profit maximization and / or minimizing cost of production. The relationship and response between mathematically modeled inputs and outputs will produce a function called Production Function (Nicholson and Snyder 2010).

$$
Y=f(K, L, M)
$$

Where: $Y$ represents the output of certain goods or products during one production period; $K$ is capital which used during production period; $L$ is Labor symbol or work time input, whereas $M$ is material or raw materials or inputs which used in production process.

Theoretically, Curtiss (2000) stated that in a competitive market economy there exists no $\mathrm{Y}$-inefficiency. Assume that the transaction costs of firms in dealing with markets are almost identical because of perfect information. The technical efficiency and competitiveness are then closely correlated and the deviations between those two could be predicted by differences between technical and allocative efficiencies. Curtiss (2000) statement based on the theory of firm behavior in a competitive market economy, it is expected that the market system encourages producers to become cost-minimizing and re-optimize their production under the new set of factor prices, in an attempt to make the marginal value product value to the factor price. Principally, Producers operating on a competitive market seek possibilities for maximization of expected profit by increasing production, especially by non-decreasing returns to scale (Jarzębowska and Rembisz, 2013).

Talking about the relationship between technical efficiency and competitiveness, Mango, et al (2015) found that technical efficiency in smallholder maize production could be increased by $35 \%$ on average through better use of available resources (e.g. land, fertilizer, seed and labor), given the current state of technology. This could be achieved through improving farmer-specific efficiency factors, which include better and more frequent extension services, smaller household sizes, and the increased involvement of male farmers in maize production. If these achieved, it can be improve the production and competitiveness of maize. They use Stochastic Frontier Analysis (SFA) to estimate the technical efficiency of maize production in Zimbabwe.

The other case showed by Reddy and Bantilan (2012) which analyzed the competitiveness and technical efficiency of groundnut oil in India using Revealed Comparative Advantage (RCA) analysis and SFA. Generally, they found that keeping the competitiveness of production of groundnut, the policy effort needs to focus on reducing huge yield gaps, which will shift the groundnut production frontier upward through the adoption of yield-enhancing low-cost technology like the adoption of improved seeds treated with rizobium and fungicide, micronutrients like gypsum, protective irrigation during stress times and use of mechanical threshers to save labor.

Generally, this research has similar final target with those previous research such a policy recommendation to increase competitiveness of commodity by paying attention to technical efficiency factor and also factor of domestic resource cost which influence production and profit of farming. So that, the aims of this research are to analyze the technical efficiency and the competitiveness of maize farming in Gorontalo Province, Indonesia. This region is one of 5 Provinces as a main exporter of maize in Indonesia (East Java, South Sulawesi, West Nusa Tenggara, Gorontalo and Lampung). 


\section{METHODS OF RESEARCH}

The research was conducted in Gorontalo Province, Indonesia. Taken 3 districts of 3 regencies as a sample of survey location. The locations are Tibawa District (Gorontalo regency), Anggrek District (North Gorontalo regency) and South Suwawa district at Bone Bolango regency. Sampling method use simple random sampling to determine the respondents of farmers. The respondent quantity of each research location were 40 farmers, assuming that the population of farmers were spread normally. So the total number of respondents in 3 (three) survey location were 120 farmers. The assumption refers to the central limit theorem, where for a large sample size $(n \geq 30)$, the sampling distribution curve will center on the population parameter value and will have all the properties of normal distribution (Juwono, 2015).

The research is address through two methodological approaches, Stochastic Frontier Analysis (SFA) to estimate the technical efficiency and the Policy Analysis Matrix (PAM) to measure competitiveness. The first methodological approach is the Stochastic Frontier Analysis (SFA), which is used to provide the study with estimates and explanation of inefficiency effects in the production behavior. The second methodological approach utilizes Policy Analysis Matrix (PAM). This methodological framework enables the calculation of different competitiveness indicators. These are then compared in their actual and technically potential terms (Curtiss, 2000).

The stochastic frontier production function used for technical efficiency analysis in this study which based on Cobb-Douglas model, with 9 (eleven) independent variables. These independent variables form the equation model of frontier production function of maize farming, which are as follows:

$$
L n Y_{j}=\beta_{0}+\beta_{1} \ln X_{1 j}+\beta_{2} \ln X_{2 j}+\beta_{3} \ln X_{3 j}+\beta_{4} \ln X_{4 j}+\beta_{5} \ln X_{5 j}+\beta_{6} \ln X_{6 j}+\beta_{7} \ln X_{7 j}+\beta_{8} \ln X_{8 j}+\beta_{9} \ln X_{9 j}+v_{j}-u_{j}
$$

Where: $Y_{j}=$ output yield of maize $(\mathrm{kg}) ; X_{1 j} \quad=$ planted area of maize $\operatorname{crop}(\mathrm{ha}) ; X_{2 j}=$ seed quantity $(\mathrm{kg}) ; X_{3 j}=\mathrm{N}$ fertilizer quantity $(\mathrm{kg} / \mathrm{ha}) ; X_{4 j} \quad=\mathrm{NPK}$ fertilizer quantity $(\mathrm{kg} / \mathrm{ha})$; $X_{5 j} \quad=$ pesticide quantity (liter); $X_{6 j}=$ herbicide quantity (liter); $X_{7 j}=$ hired labor quantity (work per day); $X_{8 j}=$ family labor quantity (work per day); $X_{9 j}=$ rent of plow tool (per days); $\beta_{0}-\beta_{11}=$ estimated parameter coefficients; $v_{j} \quad=$ random error; $u_{j} \quad=$ technical inefficiency components in model.

The expected coefficient value is $\beta_{1} \ldots \beta_{11}>0$. A positive value implies that the increase of inputs on the estimator parameter will also increase the yield of maize.

The next step is the analysis or measurement of technical efficiency. Technical efficiency analysis can be measured using the following formula:

$$
T E_{i}=\exp \left(-E\left[u_{i} \mid \varepsilon_{i}\right]\right) ; i=1, \ldots . N
$$

Where: $T E_{i}=$ technical efficiency of farmers the-i; $\exp \left(-E\left[u_{i} \mid \varepsilon_{i}\right]\right) \quad=$ estimation value of $u_{i}$ with condition $\varepsilon_{i}$, so that, $0 \leq T E_{i} \leq 1$.

The value of technical efficiency is inversely proportional to the value of the effect of technical inefficiency.

In additional, this research also measured technical inefficiency $\left(u_{i}\right)$ of maize farming. The model refers to a model developed by Kumbhakar, Ghosh and McGukin (1991), also Battese and Coelli (1995) in Coelli (1996), which considerable of technical inefficiency effect $\left(u_{i}\right)$ that reflected of farmer's social aspects. The equation for estimating the value of the effect parameters of technical inefficiency is as follows:

$$
u_{i}=\delta_{0}+\delta_{1} Z_{1}+\delta_{2} Z_{2}+\delta_{3} Z_{3}+\delta_{4} Z_{4}+\delta_{5} Z_{5}+\delta_{6} Z_{6}+w_{i}
$$

Where $u_{i}=$ technical inefficiency effect; $\delta \quad=$ estimated parameter; $Z_{1}=$ age of farmers (years old); $Z_{2}=$ crop experience (year); $Z_{3}=$ level of formal eduaction (year); 
$Z_{4}=$ member of household (person); $Z_{5}=$ total of planted area (ha); $Z_{6}=$ total of household incomes (IDR/year); $w_{i} \quad=$ random error.

Equations (2) and (4) are estimated using FRONTIER ver. 4.1, simultaneously, for consistency estimation of technical inefficiency value in equation (4) with estimated value of stochastic frontier production function of maize farming (equation 2). The process of analysis carried out two stages, the first stage is a parameter estimate $\beta i$ using Ordinary Least Square (OLS) method; the second stage is an estimate of all parameters $\beta_{0}, \beta_{i}$, variance $v_{i}$ and $u_{i}$ using the Maximum Likelihood (MLE) method. According to Coelli,et al. (2005), the results of FRONTIER 4.1 will give an estimation variance of the expected parameter closes to 1 (one) value. It means that the error term only comes from the result of inefficiency $\left(u_{i}\right)$ and not from noise $\left(v_{i}\right)$. The FRONTIER 4.1 also result the estimated log value of likelihood MLE and OLS, where likelihood log value is expected with MLE> OLS method, so production function with MLE method is good and close to field condition.

Stochastic Frontier Analysis (SFA) is a static analysis, either Policy Analysis Matrix (PAM) which the method to analyze the competitiveness in this research. Tsakok (1990) argued that there are two methods use in measuring the comparative advantage, namely: Domestic Resources Cost Ratio (RBSD) and Net Economic Benefit Ratio (NEBR). The other method or tools use were Revealed Comparative Advantage (RCA). Pearson et al. (2005) argued that Policy Analysis Matrix (PAM) was more comprehensive than the other methods use in measuring the competitiveness. The construction of PAM for an agricultural system allows one to calculate private profitability - a measure of the competitiveness of the system at actual market prices. PAM can know about the comparative and competitive advantages ratio such a Domestic Resources Cost Ratio (DRCR) and Private Cost Ratio (PCR) of commodity system and the impact of the policy.

Monke and Pearson (1989) stated that the central purpose of PAM analysis is to measure the impact of government policy on the private profitability of agricultural systems and on the efficiency of resources use. Meanwhile, social profitability and efficiency are often emphasized by economics planners whose concern is the allocation of resources among sectors and the growth aggregate income in the economy. Both of focuses on the incentive effects of policy and how policy incentives might be altered. The approach is particularly well suited to empirical analysis of agricultural price policy and farm incomes, public investment policy and efficiency, and agricultural research policy and technological change. Hence, PAM and SFA methods are relationship and supported each other.

Table 1 illustrates that PAM consists of three rows, where the first row was calculated by private price (market price), i.e. the price received by farmers. The second row was the social price calculation (shadow price) that is the price that describes the social value or the real economic value for the element of cost and yield. The both rows were calculated the profit of farming (private and social price approached). Profit is the difference between acceptance and cost. The difference in the calculation between private price and social price is due to market failure or entry of government policy located on the third row. If market failure is considered as an uninfluenced factor, so the difference is more due to policy incentives that can be analyzed (Monke and Pearson, 1989).

Table 1 - Policy Analysis Matrix (PAM)

\begin{tabular}{|c|c|c|c|c|}
\hline \multirow{2}{*}{ Items } & \multirow{2}{*}{ Revenues } & \multicolumn{2}{|c|}{ Costs } & \multirow{2}{*}{ Profits } \\
\hline & & Tradable inputs & Domestic Factors & \\
\hline $\begin{array}{l}\text { Private Price } \\
\text { Social Price } \\
\text { Effect of divergences and efficient policy }\end{array}$ & $\begin{array}{l}A \\
E \\
I=\end{array}$ & $\begin{array}{rl} & B \\
& F \\
J & B-F\end{array}$ & $\mathrm{~K}=\stackrel{\stackrel{\mathrm{C}}{\mathrm{G}} \mathrm{C}-\mathrm{G}}{\mathrm{C}}$ & $\begin{aligned} D & =A-B-C \\
H & =E-F-G \\
L= & D-H=I-J-K\end{aligned}$ \\
\hline
\end{tabular}

Source: Monke and Pearson (1989).

Notes: $D=$ private profitability; $H=$ social profitability; $I=$ output transfer; $J=$ input transfer; $K=$ factor transfer; $L=$ net transfer.

The matrix has four columns: the first column is revenue, the second column is a cost column that consisted of tradable input (fertilizers, pesticides, seeds, herbicides and tools) 
and domestic factors (labor, land and capital) (Monke and Pearson, 1989; Pearson, et.al, 2005).

According to Monke and Pearson (1989), the theoretical basis for PAM is the simple general equilibrium model of international trade rather than some social welfare function, and the matrix focuses attention on the identification of efficient patterns of production and prices. The focus of PAM in terms of identification of efficiency in production and prices is very much in line with the targets to be achieved in the analysis of production functions more specifically technical efficiency. The difference may lie only in the analytical point of view where technical efficiency is more focused on the efficiency of input volumes and other factors affecting technical production efficiency, whereas PAM is more concerned with the use of cost and socially and privately increasing production and commodity competitiveness. But actually they can strengthen each other.

\section{RESULTS AND DISCUSSION}

Technical Efficiency of Maize Farming. The model of stochastic frontier consist 9 (nine) independent variables as the factors that influenced the production of maize farming. The result of Maximum Likelihood Estimation (MLE) analysis was showed this model (table 2). The MLE method has two stages: the first is Ordinary Least Square (OLS) analysis and secondly, MLE estimation (Coelli, et al. 2005). The OLS estimate explains the average production level. OLS results are used as initial values in subsequent estimates using MLE to determine the best level of production from a combination of variables of production factors.

Table 2 - OLS and MLE of Stochastic Production Frontier Analysis of Maize Farming

\begin{tabular}{|c|c|c|c|c|c|c|c|}
\hline \multirow{2}{*}{ Parameter } & \multirow[b]{2}{*}{ Variable } & \multicolumn{3}{|l|}{ OLS } & \multicolumn{3}{|l|}{ MLE } \\
\hline & & Coefficient & Std-error & t-ratio & Coefficient & Std-error & t-ratio \\
\hline beta 0 & Intercept & 6.914 & 0.409 & 16.923 & 7.028 & 2.317 & 3.033 \\
\hline beta 1 & Planted area (ha) & 0.450 & 0.133 & $\left.3.396^{\pi \pi}\right)$ & 0.356 & 0.160 & $\left.2.223^{\pi}\right)$ \\
\hline beta 2 & seed quantity $(\mathrm{kg})$ & 0.344 & 0.140 & $2.453^{\text {(x) }}$ & 0.459 & 0.087 & $5.281^{\pi \times}$ \\
\hline beta 3 & $\mathrm{~N}$ fertilizer $(\mathrm{kg})$ & 0.079 & 0.071 & 1.107 & 0.088 & 0.292 & 0.301 \\
\hline beta 4 & NPK fertilizer (kg) & 0.082 & 0.028 & $\left.2.948^{\pi \pi}\right)$ & 0.095 & 0.033 & $2.873^{\pi x}$ \\
\hline beta 5 & Pesticide (L) & 0.000 & 0.065 & -0.001 & -0.011 & 0.063 & -0.175 \\
\hline beta 6 & Herbicide (L) & -0.019 & 0.073 & -0.259 & 0.008 & 0.036 & 0.226 \\
\hline beta 7 & Hired Labor & 0.021 & 0.098 & 0.213 & -0.024 & 0.170 & -0.142 \\
\hline beta 8 & Family Labor & -0.217 & 0.077 & -2.812 & -0.182 & 0.072 & -2.537 \\
\hline beta 9 & rent of plow tool & -0.159 & 0.067 & -2.367 & -0.189 & 0.105 & -1.804 \\
\hline \multicolumn{8}{|c|}{ Inefficiency model } \\
\hline delta 0 & constant & & & & -0.159 & 2.087 & -0.076 \\
\hline delta 1 & farmer ages & & & & 0.010 & 0.009 & 1.077 \\
\hline delta 2 & farm experience & & & & 0.001 & 0.002 & 0.385 \\
\hline delta 3 & education level & & & & 0.022 & 0.084 & 0.265 \\
\hline delta 4 & member of household & & & & 0.004 & 0.038 & 0.115 \\
\hline delta 5 & total land area & & & & 0.151 & 0.245 & 0.615 \\
\hline delta 6 & total incomes & & & & $-0.159 E-07$ & $0.392 \mathrm{E}-07$ & -0.406 \\
\hline \multicolumn{2}{|c|}{ sigma-squared } & 0.238 & & & 0.210 & 0.033 & $6.397^{* *}$ \\
\hline \multicolumn{2}{|l|}{ Gamma } & & & & 0.348 & 0.049 & $7.114^{* \pi}$ \\
\hline \multicolumn{2}{|c|}{ log likelihood function } & -78.906 & & & -71.167 & & \\
\hline \multicolumn{2}{|c|}{ LR test of the one-sided error } & & & & 15.478 & & \\
\hline
\end{tabular}

Data source: output of Front 4.1.

Note: $\left.{ }^{*}\right)=$ significant at $\alpha$ level $0.05(5 \%), t$-table $\left.=1.6587 ;{ }^{* *}\right)=$ significant at $\alpha$ level $0.01(1 \%), t$-table $=2.36041$

The result of log likelihood function MLE in table 5 is larger than the result of log likelihood function Ordinary Least Squares (OLS). These implies that the model was appropriate or close to field condition (Coelli, 1996).

Table 2 showed that there are 3 (three) variables that influence significantly to maize production. The variables are planted area, seed quantity and NPK fertilizer. It means that if those variables increased, so do the production (cateris paribus assumption). For example, if we increase the maize seed quantity $1 \%$ or $1 \mathrm{~kg} / \mathrm{ha}$, so the production will be increase $0.46 \%$ 
or $0.46 \mathrm{~kg} / \mathrm{ha}$, and so on. The gamma value in table 4 indicates that it's only $35 \%$ variation in output of maize farming system are attributed to technical inefficiency. The other explanation can be stated that there's $65 \%$ of external factors that influence the efficiency. It can be climate factor, pest and disease attack, water infrastructure etc. In additional, the value of sigma-square was significant at the $1 \%$ level (same with gamma value). It is indicates that there's correctness of the specified assumption of the composite error term distribution.

While the variables of the pesticide quantity (beta 5), family labor (beta 7) and hired labor (beta 8) and the rent of plow tool (beta 9) has negative coefficient sign, although not significant to production. The negative sign means that if adding one unit of these variables will actually decrease the production of maize as a coefficient values of each variable. For example, variable beta 8 (hired labor) have a coefficient value -0.182 , it means that if we increase 1 unit work hour of hired labor, then the production will be decrease about $0.2 \mathrm{~kg} / \mathrm{ha}$ or $0.2 \%$, and so on.

The fact on the field and based on the PAM results in Table 5 showed that labor variables, both family labor and hired labor, are the variables that spend the most cost and time of farming. As a result there is a waste of farm costs that have an impact on the increasing of production costs. Thus, it's happen of inefficiency financially and economically. Obviously, the competitiveness level of maize was influenced, directly. Related with it, Ojo (2007) argued that family labor not being use productively due to lack of adequate control during use because there was no immediate cost involvement, the tendency to over use labor from this source can't be ruled out. Therefore, if the labor will be used productively and efficiently, there should be awareness of financial commitment which only hired labor can ensure. Thus hired labor should be encouraged for improved technical efficiency. However, the Ojo (2007) statement opposite with this research found in the field, where mutual cooperation in farming can reduce labor costs and use the work time more efficiently. So the findings can be a solution to the problem of agricultural labor and also it can be recommended as an alternative policy to local governments. This fact was happened in South Suwawa District of Bone Bolango Regency (one of the survey locations).

Six variables of inefficiency effect in table 2 has no influence to the maize production, significantly. Even though, only total incomes variable (delta 6/Z6) which had negative sign in the coefficient. It means that variable Z6 has a negative influence to inefficiency effect or have a positive effect to the technical efficiency. In the other words, total incomes of farmer household have a positive contribution to the increasing of technical efficiency. It is influence to the production, directly. The fact is the farmers has a several alternative livelihoods besides farming (maize farming). Usually, they use it for farm capital too.

According to the table 3, it can be argued that actually, the age factor of farmers should not be the factor that cause of technical inefficiency of maize farming, because most farmers are in the range of productive age, which is between 20 - 50 years or 43 years on average.

Table 3 - The Characteristics of Respondent (maize farmers)

\begin{tabular}{lll}
\hline Ages & Sum of farmers & Percentage \\
\hline $15-20$ & 6 & $5 \%$ \\
$20-30$ & 15 & $13 \%$ \\
$30-40$ & 28 & $23 \%$ \\
$40-50$ & 38 & $32 \%$ \\
$50-60$ & 28 & $23 \%$ \\
$>60$ years old & 5 & $4 \%$ \\
\hline Level of formal education & & $1 \%$ \\
0 ( no schooling) & 1 & $7 \%$ \\
$1-3$ years & 8 & $67 \%$ \\
$4-6$ years & 80 & $16 \%$ \\
$7-9$ years & 19 & $10 \%$ \\
$10-12$ years & 12 & \\
\hline Farming experience & & \\
$1-10$ years & 36 & $30 \%$ \\
$10-20$ years & 47 & $39 \%$ \\
$20-30$ years & 14 & $12 \%$ \\
$30-40$ years & 16 & \\
40 - 50 years & 7 & $6 \%$ \\
\hline
\end{tabular}

Source: primary data (2018). 
Actually, if the farmer ages was in the productive range, they able to explore their ability to develop or expand the scale of farming system. The low level of education of the peasants, who mostly only attended school for 4-6 years or on average for only 7 years or only graduated from elementary school (Table 3 ). This condition causes them cannot develop and expand the farming scale. This is due to limited managerial ability and access to capital provider institutions. The variable of family members also greatly affect to the technical efficiency of maize farming. Logically, if the number of family members is large enough, then the head of household cannot depend household income on a single livelihood, such as corn farming. So the concentration of work becomes divided or just focus more on livelihoods that have a large income level.

Support those statements, Mango et al. (2015) found that household size, the region and the treatment were expected to have an ambiguous influence. A larger household could be a source of labor, which could improve efficiency. But household size could also mean high dependency on the household head, which could contribute to poverty. Poorer households are likely to be inefficient, as their economic status prevents them from acquiring the necessary inputs. Age is expected to be negatively associated with technical efficiency. So do Goldman (2013) in Mango et al (2015) who finds that older farmers tend to be more technically inefficient than younger ones. Obviously, it can be happen, because age of farmer will be influence too to the productivity of work.

Table 4 shows that the technical efficiency of maize farming in Gorontalo Province is at an inefficient level.

Table 4 - Distribution of Technical Efficiency of Maize Farmers in Gorontalo Province

\begin{tabular}{lll}
\hline Efficiency Level & Sum of farmers & Percentage \\
\hline $0.35-0.40$ & 2 & $2 \%$ \\
$0.41-0.50$ & 16 & $13 \%$ \\
$0.51-0.60$ & 27 & $23 \%$ \\
$0.61-0.70$ & 26 & $22 \%$ \\
$0.71-0.80$ & 29 & $24 \%$ \\
$0.81-0.90$ & 18 & $15 \%$ \\
$0.91-0.92$ & 2 & $2 \%$ \\
\hline Total & 120 & $100 \%$ \\
\hline Mean of efficiency & 0.66 & $66 \%$ \\
Standard Deviation & 0.13 & $13 \%$ \\
Minimum & 0.35 & $35 \%$ \\
Maximum & 0.92 & $92 \%$ \\
\hline
\end{tabular}

Source: output of Frontier 4.1.

Theoretically, it is proposed that a farm or production process can be technically efficient if the value of TE = 1 (full efficiency) (Coelli, et al, 2005; Kumbhakar, et al. 2000). However, the results obtained in Table 6 show that the average value of technical efficiency is below of 1 (one). So it is assumed that there are constraints in increasing the productivity of maize farming in Gorontalo. The similar phenomena was found by Kitila and Alemu (2014), which found the TE value $<1$. They stated that the value indicates that most farmers are not technically inefficient in producing Maize crop in the study area in that on average farmers can boost the output they are getting without increasing the existing level of inputs.

PAM analysis of maize farming competitiveness. Based on financial and economic analysis results, the net financial income earned IDR $-19,479,929 /$ year and the RC-ratio was 0.39 , while the economic net income was IDR $-10,433,635$ / year and the RC-ratio was 0.70 . This implies that maize farming in Gorontalo Province is not better financially and economically. It means that actually, the maize farming was not profitable for the farmer individually. Even though, the farmers still planted the commodity, because maize is not just a crop but it's a cultural plant for them. So, the farmers are still planting, even they get losses (personal communication with key informants). 
Table 5 - PAM of Maize farming of Gorontalo Province, Indonesia

\begin{tabular}{llllll}
\hline \multirow{2}{*}{ Items } & \multirow{2}{*}{ Revenues } & \multirow{2}{*}{ Inputs Tradable } & \multicolumn{2}{l}{ Domestic Factors } & \multirow{2}{*}{ Profits } \\
\cline { 4 - 5 } & & & Labor & Land \& Capital & \\
\hline Private & $12,231,585.68$ & $5,305,483.48$ & $18,689,065$ & $7,716,966$ & $-19,479,929$ \\
Social & $24,863,862.42$ & $12,581,422.87$ & $15,740,255$ & $6,975,819$ & $-10,433,635$ \\
Divergence & $-12,632,276.75$ & $-7,275,939.39$ & $2,948,810$ & 741,147 & $-9,046,294$ \\
\hline
\end{tabular}

Source: primary data (analyzed).

Table 5 shows that labor cost is the largest cost component of maize production in Gorontalo, followed by costs of input tradable components (fertilizers, seeds pesticides and herbicides). This result supported by MLE estimation in table 2 that explained about technically inefficient of labor variables. Moreover, the value of production cost components are greater than the revenues obtained. It can be argued that the production costs incurred by each farmer for two seasons can't be covered by the sale price of maize. Inefficiency of production cost will be influence to commodity production, directly. Hence, the maize competitiveness will be impacted too.

Consequently, tables 5 and 6 show that the value of private profitability below zero (D $<0)$ means that the commodity system earns below of normal profit. It's categorized as not yet profitable financially or unable to expand farming, while input producers earn more (personally farmers). While the value of social profitability below zero $(\mathrm{H}<0)$ means that the commodity system is not able to compete without assistance or government intervention. Furthermore, the farm is not profitable economically or there is economic inefficiency. Private profitability of maize farms is smaller than social profitability is thought to be the result of monopsony practices in the study sites. The reality condition explained that there is a dependence of the farmers on the traders or in other words collecting traders to be the only buyers of crops and farmers' places to indebted (the financial aspect) and the procurement of inputs. So that the collecting traders have the power to controlling the input and output markets, consequently the selling price of input becomes high while the purchase price of output is suppressed. This indicates a market failure.

Pearson et al. (2005) suggests that one of the causes of divergence is market failure. The market is said to fail if it is not able to create competitive pricing and create efficient allocation of resources and products. There are three types of market failures that cause divergences: (1) monopolies (market-price sellers) or monopsonies (buyers control market prices), (2) negative externalities of cost, where the party that incurs the cost cannot be burdened the resulting or positive externalities of benefit, whereby the beneficiary cannot receive compensation or rewards for the benefits it generates), and (3) the imperfect domestic factor market, in the absence of an institution capable of providing competitive services and information complete.

Table 6 - PAM Coefficients

\begin{tabular}{ll}
\hline Parameter & Value \\
\hline Private Profitability (PP) & $-19,479,928.79$ \\
Social Profitability (SP) & $-10,433,634.76$ \\
Output Transfer (OT) & $-12,632,276.75$ \\
Input Transfer (IT) & $-7,275,939.39$ \\
Factor Transfer (FT) & $3,689,956.67$ \\
Net Transfer (NT) & $-9,046,294.02$ \\
Private Cost Ratio (PCR) & 3.81 \\
Domestic Resource Cost Ratio (DRC) & 1.85 \\
Nominal Protection Coefficient (NPC): & \\
$\bullet \quad$ On Tradable Outputs (NPCO) & 0.49 \\
- On Tradable inputs (NPCI) & 0.42 \\
Effective Protection Coefficient (EPC) & 0.56 \\
Profitability Coefficient (PC) & 1.87 \\
Subsidy Ratio to Producers (SRP) & -0.36 \\
\hline
\end{tabular}

Source: analysis output of PAM. 
The output transfer in Table 6 has a negative sign. It means that the output price in the domestic market is lower than the international price. This indicates that producers (farmers) accept output prices lower than their international prices. On the other hand, these results also indicate the existence of tax policy or levies on outputs imposed on farmers producers indirectly. This result is in accordance with the reality in the field, where the actual price of maize at the farm level (local market) averaged only IDR 2,540/ kg. Whereas based on the calculation of social prices (near the world price) the farmers should get the average price of IDR 5,162 / $\mathrm{kg}$ at the farming level, while the actual world price is IDR $3,111 / \mathrm{kg}$ (http://bappebti.go.id/harga_komoditi_bursa, accessed April $26^{\text {th }}$ 2018).

Theoretically, this phenomenon shows about the existence of consumer surplus but minus for the producers (farmers). Simply, farmers as producers accept the price of output (yield of maize) is lower than the price that should be. These results clearly illustrate the phenomenon of price imbalances received by farmers, so it is reasonable if then farmers suffered losses due to high production costs are not followed by high product sales prices as well. Thus, the policy that must be taken immediately by the government is to reorganize the corn trade by imposing a government purchase price (HPP) of maize which neared to the world price.

While the input transfers in Table 6 indicates about incentives from input producers to farmers. Factor transfer (FT) in the table 3 means that there's protection to the input producer or domestic factors. The value of FT was larger than zero or positive sign, it means that there's transfer from producers (farmers) to the producers of input non tradable. On the other words, there's government policy to protect the producer of domestic factors (nontradable inputs) with positive subsidies. Meanwhile net transfer result indicated that there's decreasing of surplus producers (farmers). On the other words, the government policy cause of market distortion in output and input which happen losses for the farmers. In additional, Olagunju (2015) stated that a negative divergence between private and social profits (net transfer) indicating a tax effect for the producers. The tax effect can be from government intervention or market imperfection or both.

Private Cost Ratio (PCR) and Domestic Resources Cost Ratio (DRCR) are main indicators of competitiveness, which approached at private and social price. Table 4 shows that maize farming in Gorontalo have not competitive advantages according to PCR value. The value explains that maize farming can't able to finance the domestic resources privately. Financially, the maize farming is not profitable for farmers. Meanwhile DRCR $>1$, it means that commodity system is not efficient to finance the domestic factors in social price level, or a waste of the cost of domestic resources. Furthermore, the commodity does not have a comparative advantage and it is more profitable to import than produced domestically (in Gorontalo), because to produce the maize in Gorontalo requires the cost of domestic resources of $185 \%$ to the required import cost. In other words, every US \$1.00 cost which needed to import maize, equivalent to US $\$ 1.85$ of domestic resource costs to produce the commodity domestically. Thus, it is cheaper to import maize than produce it on its own. However, DRCR is a better indicator of efficiency in resource utilization as it corrects for price distortions (Briones, 2015; Monke \& Pearson, 1989).

Another competitiveness indicator which is an indicator of the impact of government policy is Nominal Protection Coefficient (NPC) both output and input (NPCO and NPCI). Based on the value of NPCO can be explained that the policy is disincentive to output or not protective of output, while the value of $\mathrm{NPCl}$ in table 6 implies that government policy is protective in input (subsidy for tradable input). Unfortunately, the subsidy policy of input such as fertilizer subsidy is not effective because the farmers still spend extra budget to buy the fertilizer. For example, urea ( $N$ fertilizer) price that subsidized was IDR $1800 / \mathrm{kg}$ but the farmers should be buy in the level price about, on average, IDR $1900-2000 / \mathrm{kg}$, because they have to pay the distribution cost. So, it's better for the government to change the subsidy for fertilizers from subsidy of gas material to subsidy of distribution or transportation costs.

While the EPC result implies that the level of government protection is low for protect the maize product, or policy has not been effective in protecting the maize products of 
farmers. In this case, protection policy is situational, where only export commodities, such as maize can obtain protection while imported commodities should not be protected. Supporting this statement, Salam and Tufail (2012) found that wheat commodities do not receive protection or incentives when they become imported commodities. This is understandable as import commodities can threaten the survival of domestic commodity farming. Therefore, the policy of import tariff, especially for imported food commodities is often carried out by developing country governments, solely to protect the same commodities produced by local farmers.

The value of Profitability Coefficient (PC) and Subsidy Ratio to Producer (SRP) in Table 6, respectively, means that the policy of input subsidy is detrimental to farmers (transfer of farmers is bigger to consumers) and the policy has been making farmers expend more cost in maize production.

Overall, according to those results, the output policy, input policy and input-output policy of government were not effective to increase the level of maize competitiveness. The government must reorganize the tax policy of commodity, distribution cost subsidy and the most important is the government purchase price policy.

\section{CONCLUSION}

The results of this research indicate a close relationship and mutual influence between technical efficiency with competitiveness aspects of a farm. In the case of maize farming in Gorontalo Province, several things that can be concluded are as follows:

Maize production in Gorontalo Province is significantly influenced by planting area, seed quantity, and NPK fertilizer quantity. Meanwhile, other production factors such as N fertilizer, pesticide, herbicide, hired labor, family labor and rent of plow tool, have no effect on maize crop in Gorontalo.

Although, hired labor, family labor, rent of plow and pesticide quantity were not significant effect on maize production, but has a negative coefficient sign in the model, which means that the addition of the use of these variables will actually sharpen the decrease of maize production.

Second conclusion is relates to the results of the PAM analysis that places the labor factor as one of the two most inefficient production factors in production costs. Other production factors that wasteful of cost are tradable inputs (seeds, fertilizers and pesticides/herbicides).

Excessive production inputs make maize farmers in Gorontalo on average inefficiently technical in their farming activities. As a result, the maize farming system in Gorontalo is not able to finance its domestic resources, both privately (financially) and socially (economically). This has an impact on the decline of Gorontalo maize competitiveness, both competitively and comparatively.

Policy implications. The policy that the government should immediately take is to reorganize the maize trade by imposing a government purchase price (HPP) of maize close to world prices (international price). In order to protect the yields of local farmers can be more effective, but considering that Indonesia has ratified several global free trade agreements such as WTO, AFTA and MEA, the implementation must be done carefully so that Indonesia will not be harmed by the claim of other producer countries that are also members of those free trade organizations.

To solve the inefficiency and high cost problems in farm labor, it's better for the government to make legal rules of the mutual cooperation in farming. Because it can be reduce labor costs and use the work time more efficiently.

\section{REFERENCES}

1. Briones, R.M. 2015. Domestic Resource Cost in Philippine Agriculture: Measuring Global Competitiveness of Key Commodities. Philippine Journal of Development, 42 (2): 157 184. 
2. Badan Pusat Statistik (BPS) Provinsi Gorontalo, 2010, 2011, 2016. Gorontalo Province in Figure 2010, 2011, 2016. BPS-Statistics Gorontalo Province, Indonesia.

3. Bappepti. 2018. Price List of Commodities. http://bappebti.go.id/harga_komoditi_bursa, accesed April, $26^{\text {th }} 2018$

4. Coelli, T.J., D.S.P.Rao, C.J.O'Donell, G.E.Battese. 2005. An Introduction to Efficiency and Productivity Analysis. Second edition. Springer Science and Business Media Inc. USA.

5. Coelli, T.J. 1996. A Guide to FRONTIER 4.1.: A Computer Program for Stochastic Frontier Production and Cost Function Estimation. CEPA Working Papers No. 7. University of New England. Australia.

6. Curtiss, J. 2000 Technical Efficiency and Competitiveness of the Czech Agricultural Sector in Late Transition - The Case of Crop Production. Paper presented at the KATO Symposium Berlin, Germany, November 2-4, 2000.

7. Doll, J.P. and F.Orazem. 1984. Production Economics: Theory with applications. Willey \& Sons Publ. New York

8. Jarzębowska A.B., W.Rembisz. 2013. Efficiency-Focused Economic Modeling of Competitiveness In The Agri-Food Sector. Procedia - Social and Behavioral Sciences, $(81): 359-365$.

9. Juwono, T. 2015. Metode Sampling dan Teorema Central Limit. Universitas Surya. www.blog.complexminds.net/Presentasi_1. Accessed 26/10/2017.

10. Kitila, G.M. and B.A. Alemu. 2014. Analysis of Technical Efficiency of Small Holder Maize Growing Farmers of Horo Guduru Wollega Zone, Ethiopia: A Stochastic Frontier Approach. Science, Technology and Arts Journal, 3 (3): $204-212$.

11. Kumbhakar, S.C. and C.A.K.Lovell. 2000. Stochastic Frontier Analysis. Cambridge University Press - UK.

12. Mango, N., C. Makate, B.H. Mlambo, S. Siziba and M. Lundy. 2015. A stochastic frontier analysis of technical fficiency in smallholder maize production in Zimbabwe: The postfast-track land reform outlook. Cogent Economics \& Finance, 3 (1117189): 1-14.

13. Monke, E.A. and S.K. Pearson. 1989. The Policy Analysis Matrix For Agricultural Development. Cornell University Press, Ithaca.

14. Nicholson, W. and C.Snyder. 2010. Intermediate Microeconomics and Its Application. $11^{\text {th }}$ ed. South-Western, Cengange Learning. USA.

15. Ojo, S.O. 2007. Improving Efficiency in Food Crop Production fo Food Security in Nigeria. Agricultural Journal, 2 (1): $9-15$.

16. Olagunju, F.I. 2015. Comparative Advantage and Competitiveness of Ceshew Crop in Nigeria: The Policy Analysis Matrix. International Journal of Agriculture and Economic Development, 3 (11): 1 - 14.

17. Pearson S., C.Gotsch dan S.Bahri. 2005. Aplikasi Policy Analysis Matrix pada Pertanian Indonesia. Terjemahan. Yayasan Obor Indonesia, Jakarta.

18. Reddy, A.A., M.C.S. Bantilan. 2012. Competitiveness and Technical Efficiency: Determinants In The Groundnut Oil Sector Of India. Food Policy (37): 255-263.

19. Salam, A. and S.Tufail. 2012. Competitiveness and Comparative Advantage of Important Food and Incustrial Crops in Punjab: Application of Policy Analysis Matrix. Journal of International Agricultural Trade and Development, 10 (1): 81 - 94.

20. Tsakok, I. 1990. Agricultural Price Policy: A Practitioner's Guide to Partial Equilibrium Analysis. Cornel University Press, Ithaca. 